\title{
LIBROS CORALES EN LA CATEDRAL DE GUADALAJARA
}

\author{
P O R \\ LEOPOLDO I. ORENDAIN
}

Conserva la Catedral de Guadalajara una colección formada de noventa y seis libros de coro, entre los que hay algunos espléndidamente miniados. Estos volúmenes se hallan en bastante buen estado, a pesar de su antigüedad, gracias a que están guardados en estantes construídos exprofeso, aun cuando no quedan a salvo de los efectos del polvo, por carecer de puertas tales anaqueles.

El número de tomos es menor que los de las metropolitanas de México y Puebla. Debemos recordar que los señores capitulares de la segunda, cuando contrataron al mejor iluminador que pis $\delta$ tierras de la Nueva España, "el inclito Luis Lagarto", fue para que hiciera "ciento tres volúmenes con que se gobierna el coro para los rezos, que costaron cien mil pesos". La suma fue fantástica dado el poder adquisitivo del dinero por aquel entonces, mayo de 1600. El trabajo se tasó, para cada letra, de dos pautas cuadradas a razón de $\$ 20.00$ de oro común, y a $\$ 7.00$ las pequeñas de una pauta, "haciéndolas conforme a modelo". A estos precios debe adicionarse el importe del pasaje y gastos de viaje del artista desde Europa hasta América.

L.os libros tapatíos, en su aspecto exterior, son similares a los de otras iglesias y conventos renombrados del pais. Unos tienen las pastas de gruesa vaqueta sujeta mediante clavazón a la cubierta de madera de cedro o mezquite. En otros aseguran el cuero tachuelas de ancha 
cabeza, rematando las esquinas cantoneras de hierro, metal del que llevan amplias y labradas chapas colocadas al centro. Sobre los lomos se mira estampado el título por el procedimiento de hierro en seco, singularizándose algunos infolios por sus altas lomeras de seis y hasta ocho caballetes fileteados por grecas doradas a fuego. Los cierres son de bronce cogiendo a presión. Aun cuando calados, nada tienen de notable, ni por sus articulaciones, ni por el bronce, habiendo unos ejemplares de fines del siglo xix que de cierre tienen correas que abrochan con hebillas.

Asi como las pastas no se singularizan, tampoco hay mucho que mencionar respecto a las hojas. En su generalidad son de pergamino para las carátulas, piel que se usa en el interior cuando las iluminaciones lo ameritan. Otras son de vitela, más o menos elaborada, por lo que ve a finura y tesura. Las portadas interiores llevan escrito el nombre de la festividad, o festividades, cuyos cánticos contienen, y a la vuelta de la hoja se inicia la antifona con la primera letra de la palabra expuesta de manera espectacular, abarcando desde una pauta hasta tres, entendiéndose por esto el que la inicial ocupe el espacio de uno, dos o tres pentagramas, con las notas musicales respectivas.

El conjunto de libros lo vamos a dividir en seis series o ediciones, ateniéndonos a la fecha de manufactura que conocemos de tres, y para las restantes, nos guiaremos por los estilos de los grabados, las características de las capitulares, los trazos de los pentagramas, y la labor escrituraria.

Principiaremos por describir la que parece más antigua. Consta die trece volúmenes que tienen impreso el paso de los años en lo desgarrado de sus hojas producido de voltearlas sobre el facistol, por las raspaduras de las notas provocadas por el puntero y las manchas amarillentas, señales inequívocas del tiempo. Las capitulares abarcan una pauta. Fueron escritas por manos no avezadas en achaques ornamentales, parecen obra de un escribano de escasa imaginación, carente de experiencia, de modelos que imitar y de colores que emplear. La calidad de las letras y su iluminación son toscas. Dan la impresión de que se usaron colores mal preparados, predominando el rojo, el amarillo y el morado. Los träzos son inseguros, pobres los motivos ornamentales reproduciendo cruces, estrellas, coronas de espinas y otros objetos impersonales y primitivos. El interés de estos libros se finca en su extracción popular con los descuidos, la buena fe y la ingenuidad que Hevan aparejados los trabajos de esa indole. 
El segundo conjunto está formado de diez y seis ejemplares perfectamente escritos, parecen la labor de un pendolista. Las líneas de los pentagramas son impecables. La iniciación de los cánticos la ilustran letras de diversos estilos hechas caprichosamente, lo que revela que el artista obró por su propio impulso sin plegarse a un estilo. En la misma página vemos una letra engalanada con hojas y flores estilizadas, cual motivo de tapicería, sobre la que posan dos pájaros grifos, y otra desposeída de ornatos formando el carácter retorcidas líneas, cual si evocaran las complicadas rúbricas de los funcionarios de pluma y golilla de aquel entonces. Más adelante tropezamos con una inicial de multicolores tonos, adornada delicadamente con rosas entre el follaje. De los tallos se deslizan fantasiosas articulaciones y líneas sutiles que bien vistas figuran las fauces de un trasgo. Este duende de cara burlona hace pensar en las picardías esculpidas por los canteros (lel medioevo sobre los capiteles y frisos de las catedrales.

Otros tomos, de un formato menos grande, proceden de distintas manos. El texto y la música están escritos escrupulosamente, llevando, en vez de la inicial capitular, una imagen alusiva al motivo religioso que se evoca, de tal suerte queda pintada la Santísima Trinidad al iniciarse el canto del kyrie en la misa, la Navidad al gloria, la Cena al canon, misterios delicadamente realizados, conservando sus vivos colores ennoblecidos con toques dorados.

Un copioso grupo fue hecho entre 1765 y 1780 , se singulariza por el estilo ornamental del arabesco aplicado a las iniciales. Denota la influencia árabe por el dominio de los colores amarillo, negro y rojo en tonos fuertes, acertadamente combinados, sin haberrse deslucido ni desteñido no obstante que los fondos de la ajaraca, -lazos, adornos de lineas y florones entrelazados- son de coloraciones tenues en amarillo, azul y rosa. Las combinaciones geométricas con base del cuadrado, el triángulo equilátero, y del círculo, se desarrollan en toda su amplitud, presentándonos las más diversas formas decorativas, viéndose repetidos ejemplos de letras afiligranadas. No consta el nombre del ejecutante, ni hay escrito alguno al respecto; las fechas se saben porque en ciertos volúmenes las pusieron al final, o al calce del indice, sirviendo de ejemplo el que contiene el "oficio de Nuestra Señora de Guadalupe, las misas de las festividades de San Julián, del Dulce Nombre de Jesús, la Vigilia de Santiago, las vísperas de Nuestra Señora del Carmen, el oficio del Santísimo Rosario, y las fiestas de San Felipe Neri y San Miguel Arcángel; fecit 1781 años". 
Las más recientes obras son once, forradas de vaqueta con clavos alzados, broches de latón, lomos quemados al fuego, con cantoneras del mismo metal. En la página inicial del tomo primero se lee lo siguiente: "El M.I.V.Cabildo de la Santa Metropolitana de Guadalajara, en acta capitular de 26 de noviembre de 1883 , cumpliendo con el decreto de la S.C. de Ritos fecha 26 de abril del mismo año, ordenó que se adoptaran para libros de coro de los de la edición de Ratisbona a que refiere dicho decreto." Más abajo "Guadalaxarae fecit Salvator Berrueco in Anno Dom. MDccclxxxir". Este conjunto, que podía haber sido ejecutado artísticamente, es la negación del buen gusto, pues sólo se vio el lado utilitario, desentendiéndose de cuanto significara ennoblecimiento a sus páginas. El texto está escrito con tinta de china, así como la parte musical, desnudo de ornatos; más parece una impresión a gran tipo, que el trabajo manual de Berrueco, maestro calígrafo, dibujante tipógrafo, que sa concretó a llenar cuantos tomos hubo menester de los textos latinos y las notas musicales para cumplir con lo mandado por la Sacra Congregación de Ritos, haciendo caso omiso de la estética, la originalidad y lo idealizable.

Intencionalmente hemos dejado para reseñar al último los infolios más destacados. Son quince, cuyas ilustraciones están inspiradas en textos latinos del doctor don Sebastián Carlos de Castro, las que ejecutó Juan de Dios Rodríguez Leonardo de León Coronado. Este hábil y paciente miniaturista trabajó en ellos por veintidós años, de 1722 a 1744. Al ver su laboriosidad nos sentimos transportados a las edacles cuando para enseñar la Historia Sagrada se acudia a las imágenes, naciendo asi el arte sublime contenido en los estupendos libros miniados. El artista tuvo por finalidad interpretar, no lo que tenia ante sus ojos, sino lo imaginativo, lo idealista, lo ilusorio, lo sobre terrenal, valiéndose de formas y escenificaciones evocativas de tales aspectos.

No pudimos encontrar referencias locales, en Guadalajara, de estos dos hombres, porque entre los iluminadores de libros no son mencionados por los escritores que saben de estas disciplinas. Toussaint, Romero de Terreros y Pérez Salazar hablan de Luis Lagarto y fray Juan de Mora, como de los más antiguos, siendo de 1600 y 1606 . El Marqués de San Francisco cita a fray Miguel de Aguilera (1705-1720) y dice que "entre los libros que ejecutó para su convento de San Agustín, descuella el oficio de difuntos, en el cual muchas de las capitulares representan cráneos y fragmentos de huesos humanos y las borduras de algunos infolios ostentan emblemas alusivos a la soberanía de la muerte, 
pero todo tan artísticamente ejecutado que deja por completo de ser macabro".

El mismo escritor, más adelante, menciona a fray José de Rubio por 1758 y fray Francisco López, iluminador de los "magníficos libros de Guadalupe, Zac."; al carmelita fray Miguel Joaquín Vieyra y Carreón y a clon Andrés José Gastón y Valvuena, del año de 1770, ejecutor para la metropolitana de México, "entre otros muchos excelentes, un antifonario, que ostenta, en una de sus iluminaciones, una Asunción de la Virgen de extraña composición puesto que, si bien los Apóstoles y las Santas Mujeres que abren el sepulcro, están representados como es costumbre, la figura principal, la de Nuestra Señora, asciende al cielo en la inusitada forma de la Imagen Guadalupana".

Examinando en fecha cercana la colección de libros que guarda cl Museo de Arte Religioso en la capital, hallamos un ejemplar de icléntica factura a los de la catedral de Guadalajara en cuya primera página tiene escrito: "Este libro se hizo siendo Chantre de esta Iglesia cl doctor don Luis de Hoyos y Mier. Escrito por don Sebastián Carlos cle Castro. Agosto de 1750. Dibujó Juan de Dios Rodríguez Leonardo de Lcón Coronado. Fasibit."

Con este encuentro suspendimos nuestras pesquisas que deben encaminarse a los archivos metropolitanos, y pensamos que el Cabildo de la Nueva Galicia contrató a de Castro para la confección de los que necesitaba. Quizás de León Coronado tuvo contacto con los frasciscanos y dominicos, sus contemporáneos, que cita Romero de Terreros, ampliando nuestras suposiciones hasta imaginar que vio la obra de fray Miguel de Aguilera en el oficio de difuntos porque tiene la misma temática evocadora del reinado de la muerte.

Analizar, no digamos todo, sino alguno de los infolios nos parece cansado, laborioso e inútil, porque requeriria describir e interpretar los temas teológicos que el doctor de Castro elaboró en su mente, con mil complicaciones canonísticas para cada festividad, a lo que tuvo que ajustarse el miniaturista para expresarlo plásticamente. Esto no obstante, vamos a procurar dar una somera idea de la distribución de los dibujos y cómo se acomodaron los elocuentes textos latinos, vedada su esencia al común de los mortales.

El cantoral relativo a la domínica xv después de Pentecostés consta de 75 páginas. Se inicia con el texto: "Inclina Domine aurem tuam", que ocupa todo el espacio central de la página, porque la abarca tres pentagramas. Estas iniciales en todos los casos, están animadas con tres 
elementos, además de los adornos del fondo, grecas y arabescos. Es el primero una escena terrena en concordancia con la festividad, el segundo la invocación en plano aéreo o celestial del asunto que se celebra, y aquí ya intervienen los latines escritos en retorcidas filacterias que salen de las bocas de los personajes o se despliegan por los aires. El tercer elemento de la composición está constituido por más textos colocados en la parte inferior de la inicial, en cartelas, y sobre los márgenes.

El espacio central de la hoja está orlado por recuadros, tres a cada lado en sentido vertical, en los que se miran dibujadas las escenas concordantes al evangelio de la domínica, que en este caso particular toca al capítulo vil de San Lucas, relatando la resurección del hijo de la viuda de Nafm. En la parte superior e inferior hay escenas en cuadros de forma apaisada. Conciernen a una alegoría de la Virgen María, sin hilación con el texto del evangelio mencionado, y otra de la misma Señora sentada sobre un monte en donde la rodea un conjunto de mujeres que cantan o tañen instrumentos musicales. De las bocas de éstas se desprenden, bien circunscritas, las frases que imaginativamente Ies toca pronunciar, tomadas de los salmos 12, 31, 41 y 88, enfocadas a meditaciones sobre la muerte y la resurrección; así, por ejemplo, una de las cantoras clama "Ilumina mis ojos para que yo nunca me duerma en la muerte", del salmo 12.

En las seis divisiones de la orla se expresan pictóricamente textos del capítulo iI de Tobias, del iv de Isaías, de los salmos, y evocaciones desde el encuentro del cortejo funerario con la madre deshecha de dolor, hasta cuando Jesús entrega, tomándolo de la mano, al naimita ya resucitado ante la admiración de la multitud que entona las palabras del salmo 41: "Amparador mío eres."

Altamente interesante es el contenido del libro con la festividad del Domingo de Ramos, hecho en 1744. Consta de 100 páginas, siendo de los más profusamente ilustrados. Abre el texto con una espléndida $\mathbf{H}$ de la palabra Hosanna. La parte superior e inferior no difieren, dos recuadros apaisados, pero a los lados hay diez verticales, cinco a cada lado. Las ilustraciones están enfocadas al contenido del capítulo 21 de San Marcos, los preparativos y la entrada de Nuestro Señor Jesucristo a Jerusalem. Allí se puso a los apóstoles buscando afanosos al pollino para el Señor; cómo lo conducen para que lo cabalgue, la entrada triunfal a la ciudad, la multitud cantando hosannas mientras que agitan palmas y ramos. Se barajan temas del Antiguo con el Nuevo Testamento, porque en la parte inferior se cita el capítulo 62 de Isafas. 
Hay otra página en el mismo volumen, plenamente miniada con pasajes de la Pasión. Son ocho los pequeños cuadros laterales más los dos horizontales. Uno es un cónclave de sacerdotes de la ley mosaica que cantan el salmo 21 y otro rememora el capítulo 22 de Isáas. Lọs verticales representan los diversas sucesos del día, tales como: La última cena; la oración en el huerto; los apóstoles dormidos; los demoniọs intentando tentar al Señor, de una emotividad sorprendente por la expresión de las figuras; el beso de Judas, quien habla diciendo: "Ave Rabi"; la aprehensión del Maestro, que avanza y exclama: "Ego Sum"; el milagro de la oreja de Malco; los soldados romanos llevando prisionero a Jesús.

El volumen con los rezos del domingo xvir después de Pentecostés fue mutilado por indoctos iconoclastas, hallándose la portada, sin saber de donde procede, en el Museo de Guadalajara. Ese tomo consta de 73 páginas con capitulares intercaladas en los dibujos miniados aplicados a la letra $M$.

Los antifonarios más hermosos, con mayor número de pinturas $\mathrm{y}$ abundantes páginas son dos, correspondientes a los oficios de difuntos conteniendo la misa y las horas mayores y menores. Uno abre el texto con una $\mathbf{R}$ monumental y a partir de ella hasta la última de las iniciales, todas tienen motivos funerarios o luctuosos, estando figurados los rasgos de las letras mediante huesos ditribuidos en formas caprichosas, pero sin perder su naturaleza.

Alli aparecen las "muertes" de convulsos movimientos, con las nerviosas posturas que toman las hechas de alambre por nuestra manufactura popular. De León Coronado las reprodujo con actitudes tan veristas, a veces picarescas, como para burlarse de los humanos. No falta el clásico esqueleto con increíbles contorsiones barajándose con los jinetes apocalípticos. Esas figurillas no andan con las manos vacías; portan la aterradora guadaña. Otras veces ejecutan ademanes elocuentes como el de indicar se guarde silencio, para lo cual, se llevan la descarnada mano a la altura de la reluciente dentadura a la que aproximan el indice, dando imperativamente orden de callar.

La capacidad imaginativa del miniaturista se revela en estos libros más que en los otros, porque muestran cómo supo concebir simbolismos o alusiones convencionales en un plano humano. Como Gerónimo Van Aeken "El Bosco", crea en su mente los monstruos compañeros del demonio y de la muerte. Inventa un mundo ilusorio. Concibe unos seres para que actúen en lo irreal, enardeciendo e impulsando los 
sentimientos religiosos. El pintor se propuso manifestar el horror, el temor ante lo ignoto trasmitiéndolo con sus imágenes. Cuando pinta los ángeles hace esfuerzos para darles aspecto de genios del bien, sin conseguirlo; pero sí lo logra con los genios del mal a quienes da la apariencia espantable, tal cual conviene para flotar dentro de la atmósfera espiritual para cuyo fin se le encomendaba crearlos.

Deben haber considerado los autores -De Castro y Coronado- que estos dos libros eran la suma de su obra, porque en uno de ellos pusieron sus nombres en lugar prominente, como lo diremos, y en otro, robando gran espacio de la página inicial escribieron este texto:

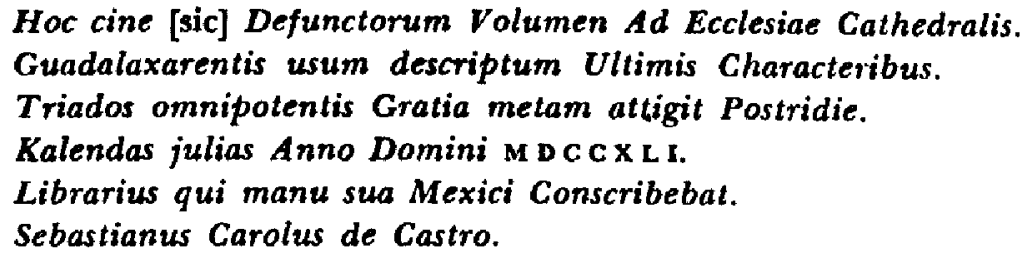

(Este libro de Difuntos, escrito para el uso de la Iglesia Catedral de Guadalajara, en caracteres modernos, quedó terminado, por la gracia de la Trinidad omnipotente, el día 2 de julio del año del Señor de 1741. El escriba que de su mano lo escribió, en México, Sebastián Carlos de Castro.)

El ejemplar, con lo transcrito, consta de 121 páginas y de 90 el otro, que presenta la particularidad de tener la carátula con una historiada orla diferente de todas las demás por carecer de recuadros. En la parte superior están los tres símbolos de la grandeza terrena colocados sobre sendas calaveras, siendo la tiara, la corona imperial y la diadema real. Ese mismo elemento se repite por ambos lados de la página, llevando por cimera lo que corresponde a cada dignidad humana desde lo más alto, que ya quedó dicho, hasta lo más vil, el mísero sombrero desbordado de un mendigo; de esta suerte se ven los cráneos cubiertos por mitras, coronas nobiliarias, birretes, morriones, bonetes eclesiásticos, cascos de militares, almetes, turbantes y capuchas. Entre uno y otro de estos cráneos simbólicos están manifestadas las edades del hombre en seis etapas desde niño al nacer hasta el anciano decrépito. En la parte inferior se mira un cadáver putrefacto; sobre él se extienden dos listones flotando, haciendo pliegues; en ellos están escritos los nombres completos del doctor de Castro y del miniaturista Coronado, así como el año de ejecución, 1741 . 
DOI: http://dx.doi.org/10.22201/iie.18703062e.1960.29.689
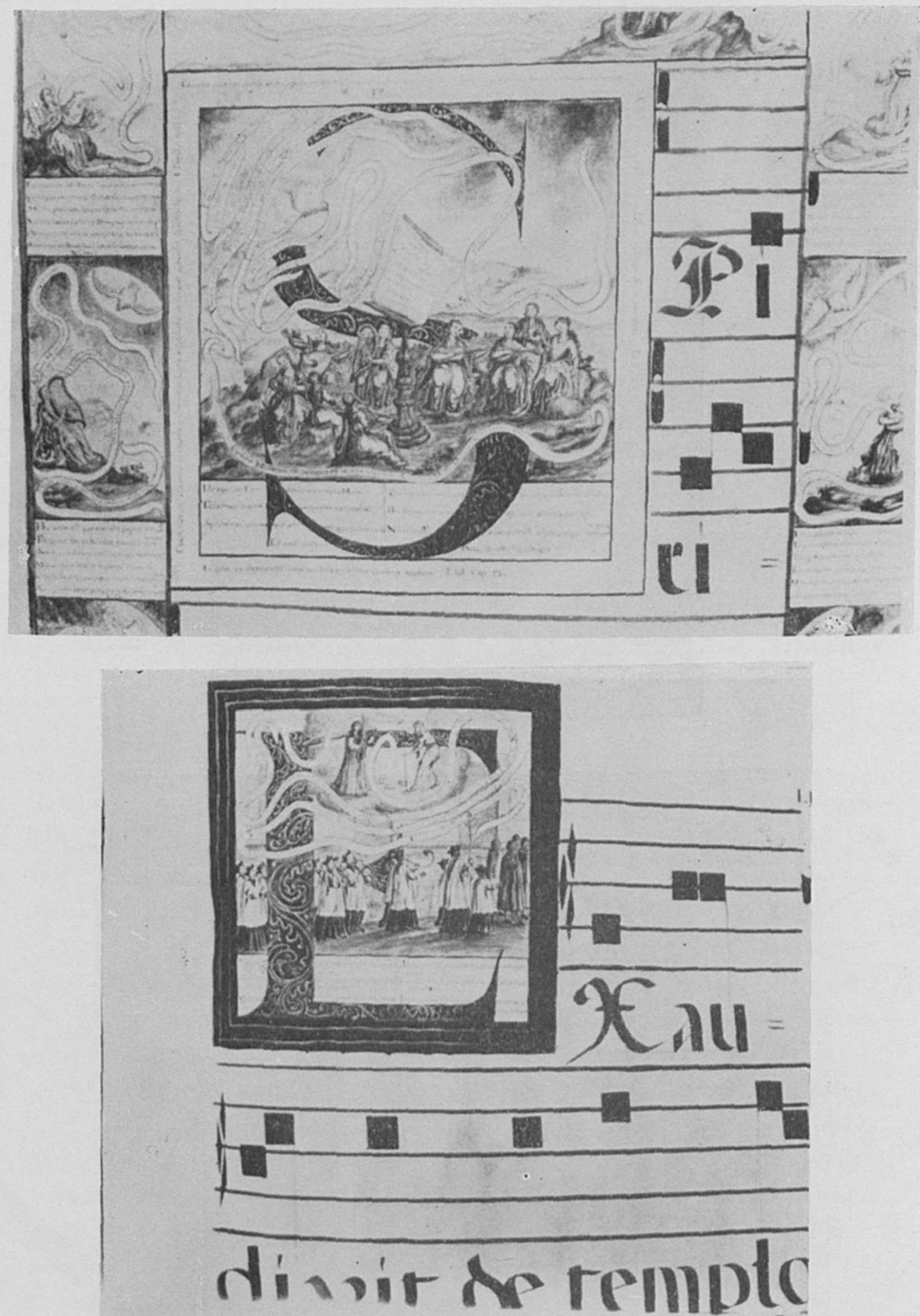

l y 2. Dibujos de Capitulares. La primera con escena del Exodo; la segunda una procesión. 

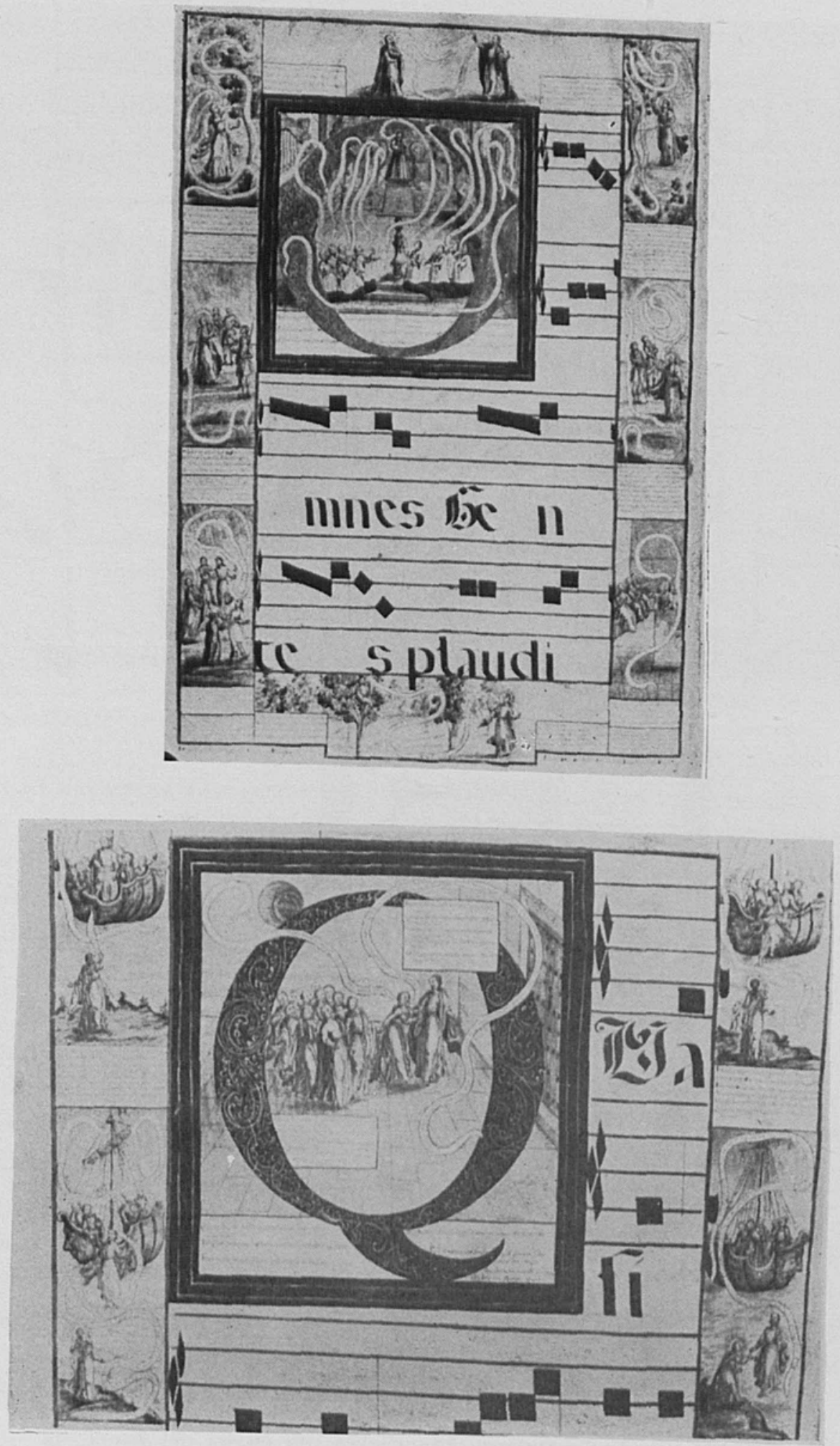

3 y 4. Dibujos de Capitulares con motivos alegóricos. 


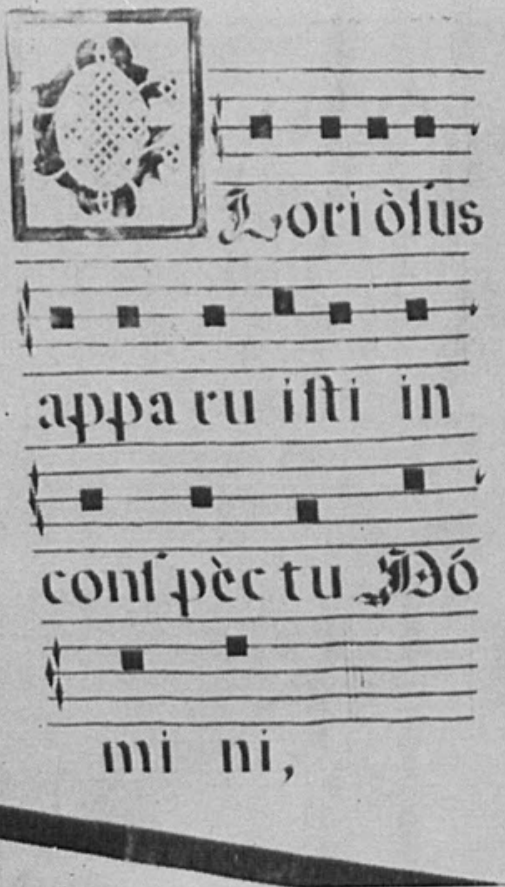

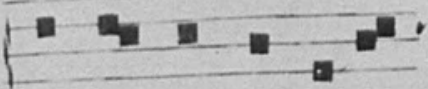

5. Alle lu ia, a tle

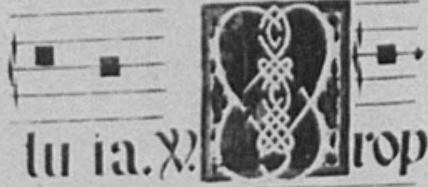

$\div \square$

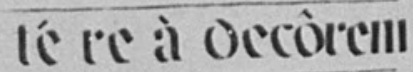

$\because$ ill cuil lc oómili
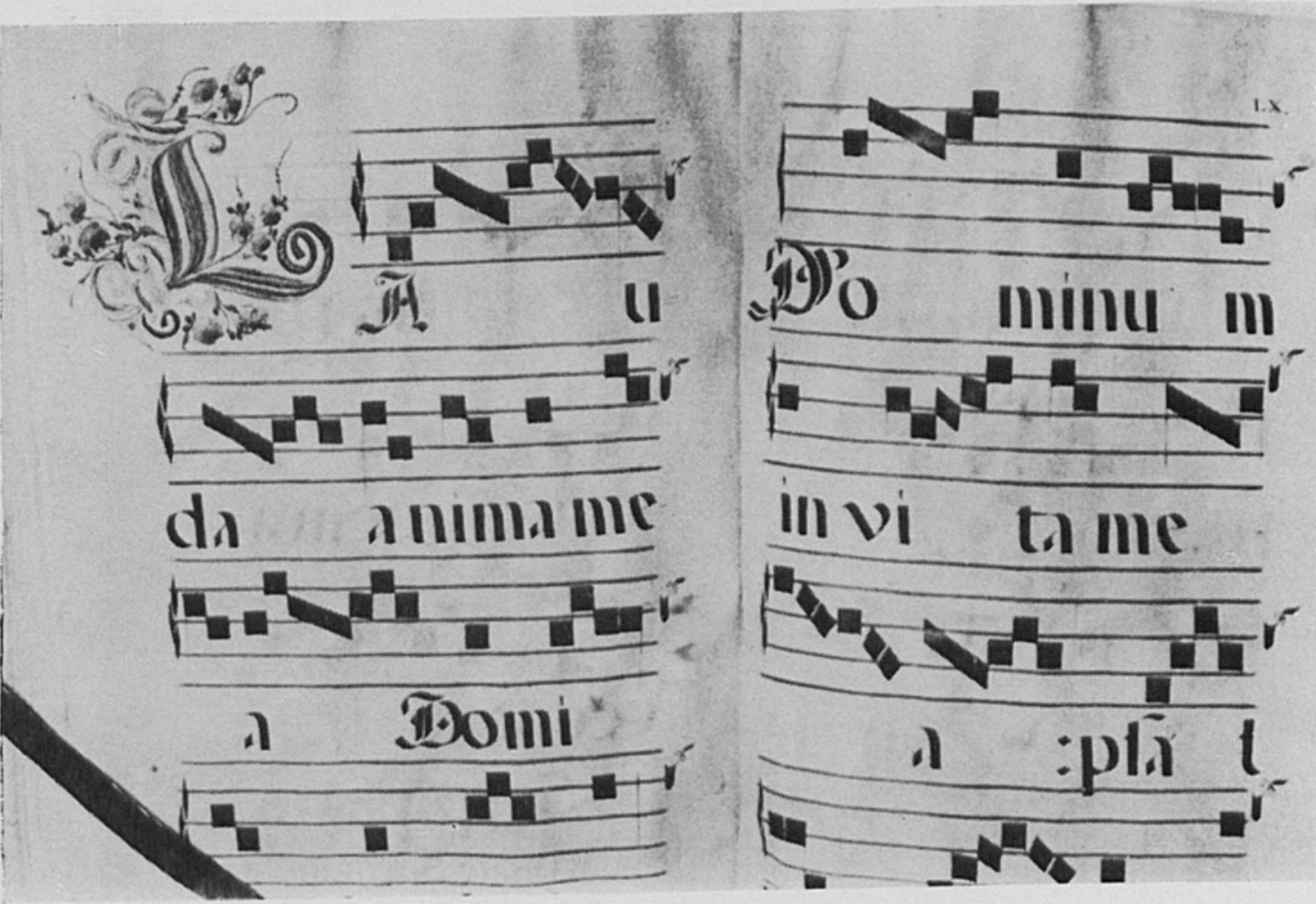

5 y 6. Edición de 1781. Ornamentación de arabescos. Edición con capitular adornada de flores. 
DOI: http://dx.doi.org/10.22201/iie.18703062e.1960.29.689

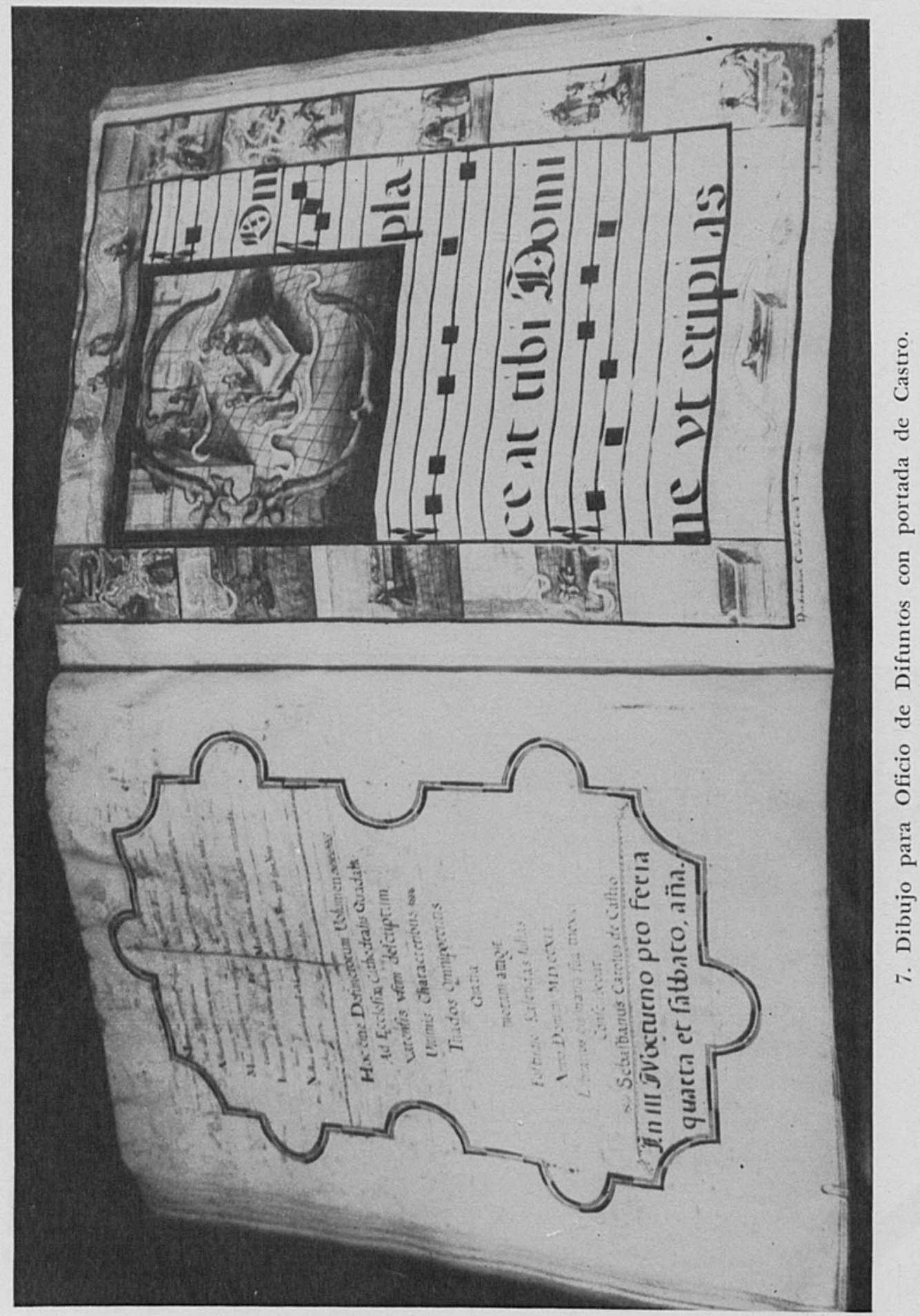


DOI: http://dx.doi.org/10.22201/iie.18703062e.1960.29.689

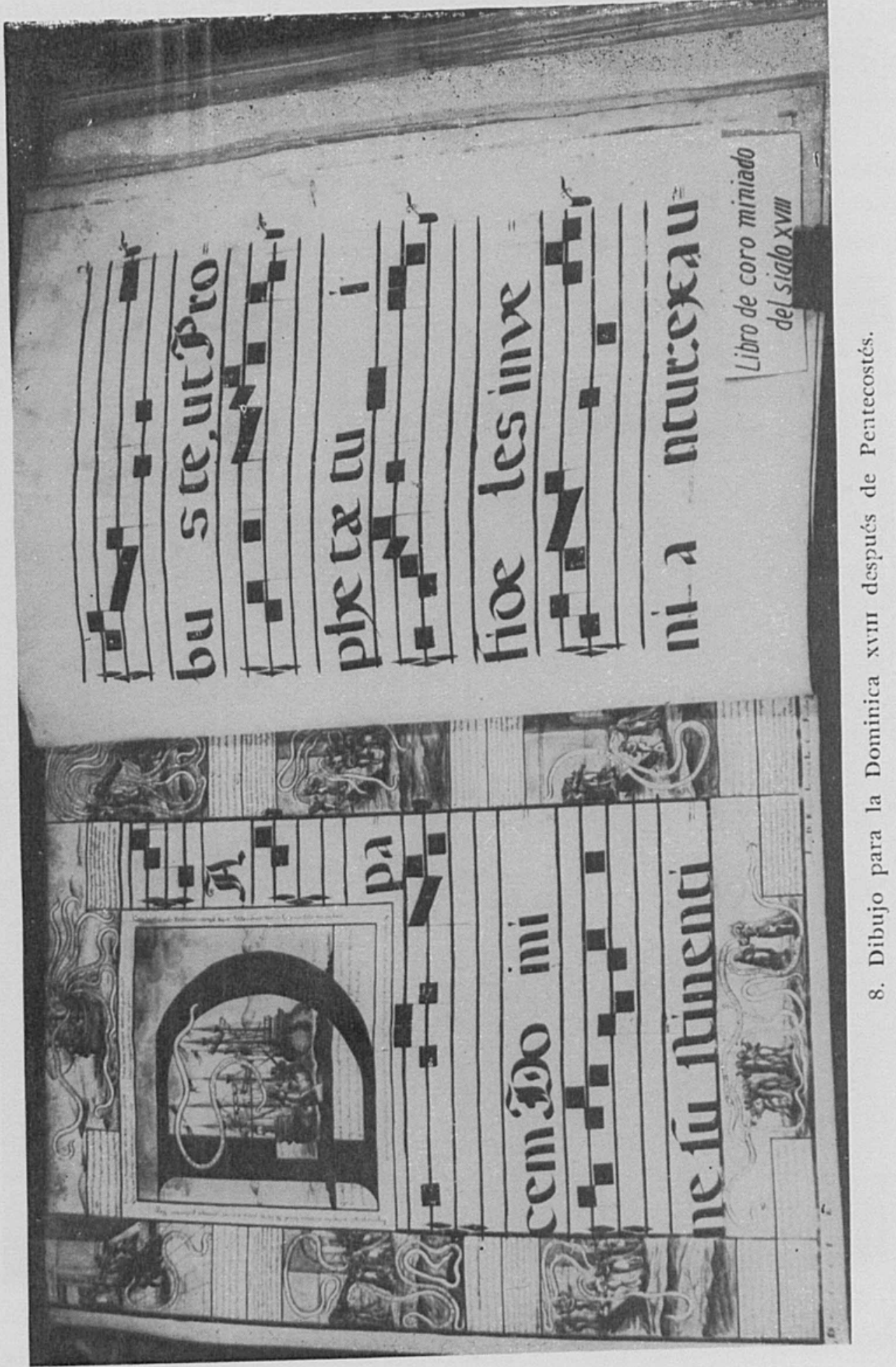


DOI: http://dx.doi.org/10.22201/iie.18703062e.1960.29.689

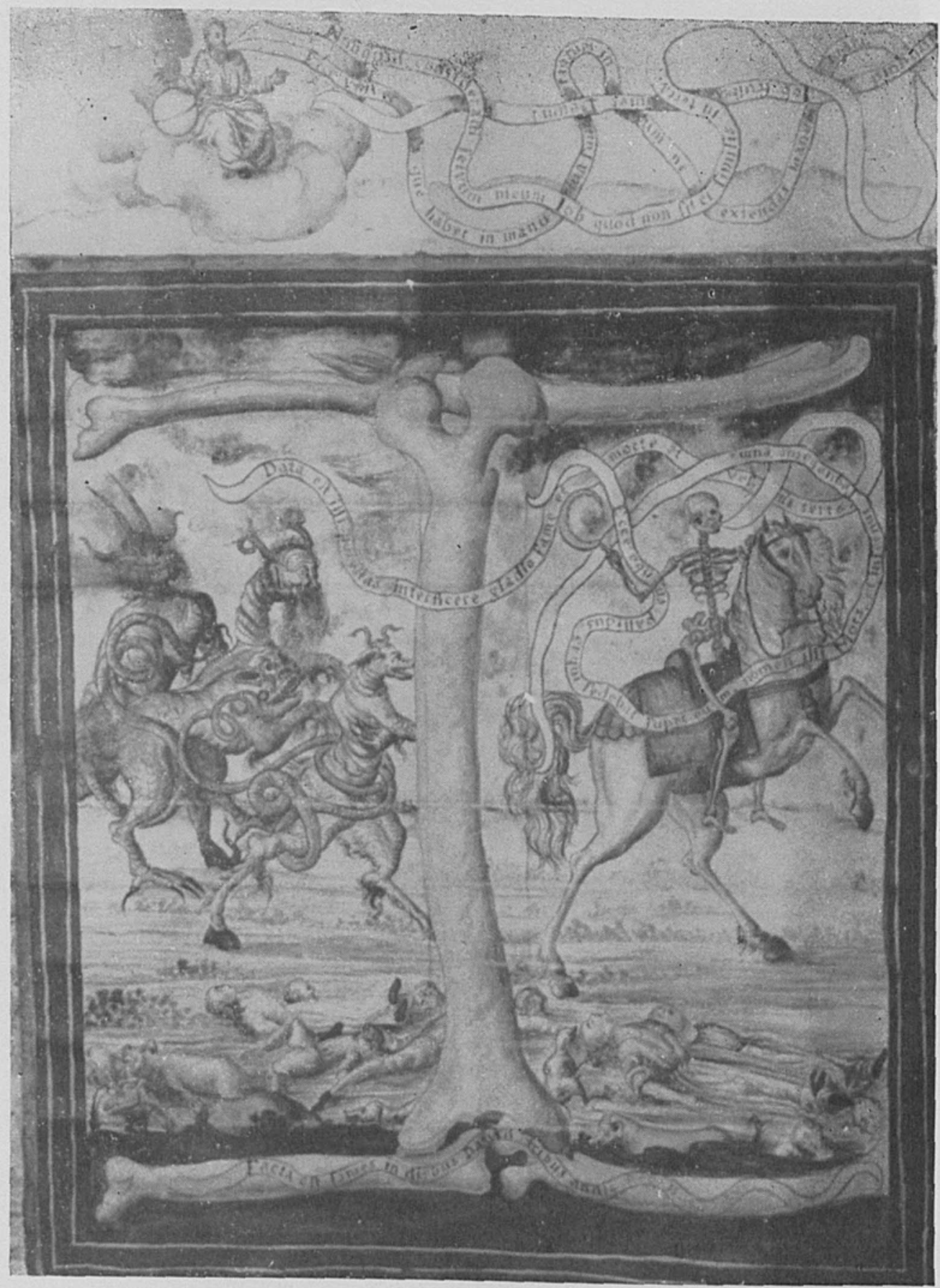

9. Dibujo para Oficio de Difuntos. 
La inicial de la portada corresponde a la letra $\mathbf{P}$ que tiene de fondo una sombría escena del Calvario. Yéndonos a la páginas 28 encontraremos otra gran hoja miniada consagrada al purgatorio y la eficacia de la misa aplicada por las ánimas. Sobre una $M$ hecha con fémures y tibias está un guerrero jinete de un brioso corcel que parece espantarse a la vista de los difuntos, cuyas obras las pesa el caballero en una balanza.

Para referencias daremos una relación de los volúmenes restantes, prescindiendo de descripciones sobre las ilustraciones que contienen, indicando tan sólo lo más relevante, o algo que los singularice. Iniciaremos por los que contienen el rezo de las domínicas vil y xviı después de Pentecostés con 83 y 75 páginas respectivamente. Capitulares: $\mathrm{D}, \mathrm{E}, \mathrm{O}, \mathrm{P}$ y $\mathrm{S}$, con aplicaciones doradas.

Volumen de la Domínica Iv de Cuadragésima con 82 páginas; carátula representando el milagro de la multiplicación de los panes. Los letreros en cintas y filacterias contienen citas de Virgilio y Ovidio. Capitulares destacadas la $\mathrm{C}$, la $\mathrm{S}$ y la $\mathrm{L}$. La Domínica de Pentecostés ocupa 75 páginas, fechadas en 1744; los motivos musicales privan en la primera hoja y todo está aparejado al Espíritu Santo que destaca en cada episodio bajo la figura de la simbólica paloma. Uno de los más antiguos libros es el de la Domínica in Albis, hecho en 1724. Contiene 52 hojas a gran formato, siendo oportuno hacer constar aqui que todos los libros tienen diversos tamaños a lo ancho y largo.

Un infolio de 113 páginas, hecho en 1723 , contiene los cánticos del jueves y viernes santos, siendo los temas relacionados con la Institución de la Eucaristía y escenas de la pasión. Conviene examinar en la página 80 una $C$, que tiene de fondo un paisaje donde se ven las tres Marías -Magdalena, Jacobi y Salomé- encaminándose al sepulcro del Señor, llevando ungüentos aromáticos y cirios encendidos con que guian sus pasos al amanecer. Correlativo con este tomo viene el del Domingo de Resurrección que consta de 72 páginas. La de la portada tiene una encantadora vista del huerto donde se hallaba la sepultura del Salvador, quien habiendo tomado carne gloriosa deja confundidos a los soldados que la custodiaban. Aquí tenemos un detalle de indecible ingenuidad, no son los humanos quienes hablan, sino las flores. En cada una de ellas hay escrita una palabra y de las plantas salen las filacterias cantando las glorias del resucitado. Las escenas correlativas a la festividad principal se plasman en los recuadros de las iniciales, donde cambian las horas corales, estando en la página 25 el pasaje del cenáculo; en la 36 el de la pesca milagrosa; en la 46 la del sepulcro vacío; en la 58 la aparición 
a los apóstoles y en la 69 el encuentro de María en el huerto bajo la forma de hortelano.

De 147 folios es el ejemplar que contiene diez misas para las festividades de pontifices, mártires, confesores, doctores, abades y obispos. Además de la portada a todo color, en las páginas $15,27,40,61,75$, $91,106,120$ y 136, que corresponden a cada misa, hay su respectiva capitular alusiva a la ocasión y al santo que se conmemora.

Otro tomo con idéntico número de hojas es para el común de los santos, vírgenes y mártires. La primera inicial es una $L$ con el tema de la Samaritana. Orlan la página las imágenes de San Felipe, San Antonio de Padua, Santa Rosa de Lima, Santa Catarina, San Sebastián $y$ otros muchos bienaventurados unos solos y otros en grupos.

Para dar término a esta enumeración falta el libro que tiene escrito lo que concierne a las Vigilias de los Apóstoles y doce misas más que completan las de los santos y discípulos del Señor, estando expresados los hechos salientes de la vida o muerte, según corresponde en los fondos que llevan letras con que se inician las misas en la primera de las 136 páginas y luego en las números $10,23,45,56,65,73,86$, 97,106 y 118. 